\title{
The Connotation and Development Path of the Integration of Preschool Education
}

\author{
Liangying Yang ${ }^{1} \&$ Li Jing $^{1}$ \\ ${ }^{1}$ Faculty of Education, Southwest University, Chongqing, China \\ Correspondence: Liangying Yang, Faculty of Education, Southwest University, No. 2 Tiansheng Road, Beibei, \\ Chongqing 400715, China. E-mail: 1144731568@qq.com
}

Received: September 23, 2014

Accepted: November 22, 2014 Online Published: February 12, 2015

doi:10.5539/ass.v11n5p74

URL: http://dx.doi.org/10.5539/ass.v11n5p74

\begin{abstract}
Education Integration is the fundamental experience of the world's preschool education development and also the strategetic objective of China. The essence of China's preschool education is energetic, healthy and sustainable and connotative progress. The basic methods are as follows: Fortifying the reform of education system to promote the realization of education integration in the city and the country; enlisting education objectives and contents to build educational network service and implement integration of education and service under the guidance of the government; Accelerating pre-school education legislation and improving teachers' qualification examination system to establish incentive mechanism to consummate childcare integration.
\end{abstract}

Keywords: preschool education, integration, developing methods

\section{Introduction}

Education Integration is the fundamental experience of the world's preschool education development and also the strategetic objective of China. The education for Children between zero to six years old are our country's developmental strategy and the responsibility of future development. The USA put forward the idea "children are the big fortune in a country" (Morrison, 2004). In 2010, China published the National Medium- and Long-Term Plan for Education Reform and Development (2010-2020), in which it pointed out the developmental aim in China is general popularization of preschool education and the priority of developing rural preschool education. Popularizing quality preschool education and implementing fair, high quality and sustainable development of preschool education from the integration of urban and rural integration, nursery, education and service integration design on the top, so as to build the overall development of China's preschool education integration framework.

\section{Literature Reviewing}

\subsection{Pre-school Education between Urban and Rural Integration}

The government is the main body while system is the key in the realization. Lv Ping et al. (2010) pointed out that the government shoulders main responsibility to balance urban-rural education development; preschool education should be concluded in public service system so build urban-rural integration and to balance its development; fiscal investment need to be increased and it's necessary to establish a rational fiscal investment of preschool education; to promote a balanced preschool education development, the duty of supervision should be emphasized, and market, society and families each serve their responsibility. Teachers are the key element in the realization of preschool education integration. Cao Yuan et al. (2011) put forward teachers' personnel system is the bottleneck to achieve urban-rural preschool education integration. There needs the restructure of teacher supply mechanism, urban-rural teacher exchange mechanism and teacher training system.

\subsection{Child-care Integration}

Yu Yongping (2008) proposed that it needs scientific policy and education as its orientation and unique course concept to achieve childcare integration. He Feng (2012) introduced backgrounds, institution, course design, teachers' training, service and etc of childcare integration between zero to six in Britain, Japan and Taiwan. Besides, he made analysis of their legislation, programs, supervision and evaluation system. 


\subsection{Caring and Education Integration}

Caring and education integration mainly makes rules upon legislation and courses. (HM Treasury, 2003) In the British law Childcare Act clearly pointed out preschool children service should contain early education, caring service, social service related to children and their parents, health care service, employment and training service, information supply and other supportive service. (Zhang, 2011) In September 2008, Britain promulgated The Early Years Foundation Stage. EYFS for short integrated Importance between Zero to Six Years Old, National Standards of Daycare and Home Nanny of Children under Eight, and Course Guidance for Basic Phase to build course framework of learning, development and caring for children under five years old.

\section{The Inner Meaning of Preschool Education}

Education integration is the product of social development and the direction of different countries' education reform. Under different historical backgrounds, each state had their own understanding. Preschool education has distinct social and historical characteristics. Since 1990s, with the realization that the early childhood education was deeply connected with life-long education and globalization, people's attention fixed on pre-school education. In 1972, UNESCO presented the concept of lifelong learning and education socialization in the report Learning to survive - The world of today and tomorrow, becoming the direction of early childhood reform and development. The orientation of pre-school education reform is the linking up of kindergartens and elementary schools and the integration of institution, family and society. (Feng, 2000) Since 1990s, with requirements of early child education increasing and the development of science and technology, the world attached more and more importance to early childhood education, as well as its role in social development. The tendency can be called early childhood education integration. Education integration embodies itself from two sides. Vertically it means early childhood education includes new-born baby and is a part of lifelong education. Horizontally, it stands that kindergarten, family and society are all responsible for nourishing children, and thus promoting its development. With its historical characteristics, the integration is the orientation of the world's preschool education and the product of social development. Urban-rural integration is the fundamental feature of China's society, a special fruit of social development and the practical solution to and essential requirement of our country's education. Realization of urban-rural integration is the strategetic policy and an important task of preschool education.

Integration of preschool education is the practical appeal of its development, that is to say, to unify childcare between the year of zero to three and three to six and to fuse institution education with social service and to establish social public service system. The frame is to pursue an independent and complementary education system with fairness and high-quality as its orientation while abiding by preschool education theories and regulations. Its essential requirement is to realize a healthy, sustainable and connotative preschool education development. Thus, what preschool education means in China is that in the new urban-rural relationship. It's essential to achieve a fusion of urban-rural education, education and social service as well as a fusion of daycare and kindergartens in case of preschool education. Meanwhile keeping eyes on fairness and quality, thus to obtain a balanced education development and maximally realizing the unification of the progress and outcome of preschool education. It's China's our country's strategetic choice to pursue an integration of urban-rural preschool education, education and service and daycare and kindergartens.

\section{The Development of China's Preschool Education Integration Path}

\subsection{The Integration of Urban-Rural Preschool Education}

In the course of preschool education, we need to construct the integration of preschool education in the city and also the countryside in order to coordinate the development of urban and rural education, integrate educational resources, promote the mutual complementary educational resources and realize the integration of urban and rural educational development goals. So, what is urban-rural preschool education integration. (Zhang, 2012) The connotation of the integration of urban and rural education is the education development between urban and rural areas as a whole, to achieve resource sharing, mutual integration between urban and rural areas, harmonious coexistence and common development. Integration of urban and rural development needs to create institutional mechanisms and reform the education system in order to provide protection for achieving the integration of urban and rural preschool.

4.1.1 Reform the Personnel System, Promote the Integration of Urban and Rural Pre-school Education Teachers

High-quality teachers are the key elements to realize urban-rural preschool education integration. First is to optimize teachers' group, improve teachers' appraisal and hiring system to keep structural balance on teachers' age, education and title. Second is to enhance teachers' salary through establishing a rational mechanism that the 
government, childcare institution and parents share to undertake. And salary tilt policy should be applied in poor areas to stabilize rural teachers' staff and at the same time to attract more high-quality teachers to teach there. Third is to build incentive system and circulating mechanism of teachers of urban-rural preschool education. Education department lays down incentive system and offers a proper preferential policy to rural teachers, and correlates teachers' title assessment with teachers' evaluation. Besides, education department should encourage urban teachers to work in rural schools and apply salary tilt policy to rural teachers especially those working in remote areas.

\subsubsection{Improve Investment System and Establish Financial Integration of Urban and Rural Preschool}

Increasing financial input and owning a reasonable supply system in urban and rural areas are the foundation and an important guarantee of the development of preschool education. First, we should establish "the provincial level, local-based" investment mode, change the "county-based" financial mode, establish provincial government's coordinating system, clear the responsibilities of various departments at all levels and establish the relative concentration of investment patterns. Second, we should focus on the development of rural preschool education and establish urban and rural public financial investment mechanism. Government's fiscal policy tilts toward rural areas and increases investment in rural kindergartens so as to provide basic financial security for the development of kindergartens. Third, we should establish a reasonable "government, organizers and the family" cost-sharing mechanism. According to the level of local economic development, government procurement services, organizers and parents should be distributed in a reasonable proportion, we also should formulate charging standard, while providing special subsidies to those disadvantaged children.

4.1.3 Exploring the Supply and Demand System and Pursuing the Realization of Preschool Education Integration of Resources

Education resource is necessary to promote urban-rural preschool education development. First, we should build a pattern that education is mainly run by the government while the society also takes part in, a balanced pattern that public education and private education both boom. Then we can reform the system of kindergartens, support the development for inclusive and private kindergartens so to construct a broad and fundamental preschool education public service system. And in order to achieve a joint development. It is necessary to build top and demonstrational kindergartens in rural areas in our society. Second is to set a rational urban and rural kindergarten layout. Measures are to put school layout in the constructions of cities and towns and take the urban-rural development, changes of school age population and distance into consideration so that kindergartens both in urban and rural areas could form a complementary mechanism of mutual assistance. Third is to improve operating conditions of preschool education in rural areas which demands a clear legal responsibility of government at all levels and increase financial transfer payments. Thus a multilateral resource disposition system is founded to balance urban-rural preschool education development. Fourth is to strengthen standardization of urban-rural kindergarten construction both in the hardware and software conditions for example infrastructure, education toys, amount of books, school building, courses and teachers.

\subsection{Integration of Education and Service}

Integration of preschool education means providing services for children, such as education, nutrition, immunity, physical examination, consultation and informal learning. In 2003, the green book issued by the British government pointed out that in order to create an integrated service frame including education, health and social service, children and family service need restructuring (UK Parliament, 2006), so to narrow children's developmental differences and improve their performances.

\subsubsection{The Government Guidance, Encourage Social Forces to Run the Kindergarten and Social Service Agencies}

It's an important method that under the guidance of the government, nongovernmental sectors are encouraged to run schools and social service institution so to realize the integration of education and service. With the encouragement of government department, conglomeration of high quality kindergartens should be implemented and they are encouraged to radiate out to rural areas. Different institutions or groups are encouraged to run special kindergartens of multi-types and multi-levels and service institution. In addition, social welfare institutions and civil organizations are encouraged too. What's more, to provide childcare, education and social service for poor and low income family, partially deducing fees or free of charge will be carried out.

4.2.2 Goals and Content of Children's Development Should Be Clear and Comprehensive Service Should Be Provided

As British government's Green Paper "Every Child Matters" in 2003 pointed out that we should reconstruct the way children and family serve in order to create a integrated service framework that covers education, health and 
social services for children and adolescents (HM Treasury, 2008). If so, we can narrow the development gap among children and improve the development achievements of all children. That goals and content should be clear is both the start and end point of children's comprehensive service. They are made according to children's mental and physical development and their needs so that goals suit their development. The comprehensive service of children's development contains four aspects: first is to boost nutrition and health level of children between zero to six; second is to enhance adults' ability of scientific nurturing and caring; third is to lay the foundation for children's physical and mental development; fourth is to enact policies and fulfill each department's functions. According to such goals, the content is to provide early education and childcare such as nutrition, immunity, health examination, consultation and informal education, etc. Besides, the integration of education and service educates and nurtures children and provides adult education, parenting and support, especially to disadvantaged children. It's an integrated one that includes health, learning, growth, communication and service.

\subsubsection{Adjust Measures to Local Conditions, to Establish a 0 to 6 Years Old Preschool Education Network} Service

Building preschool education radiating system is an important measure to promote preschool education and enlarge scopes of services. First is to build a "three-level" internet service of preschool education in a county, to promote its development in rural areas which should be incorporated in public service system and to speed up the construction of rural kindergartens. It's to build and perfect a "three-level" internet service of preschool education which is of county, town and country. Second is to launch the city-driving country, demonstrational kindergarten-leading-common kindergarten mode. Social environment, economy and culture differ a lot in China. To cover urban-rural service activities, preschool education internet system must be established according to actual conditions in each place. All provincial departments make planning and support policies while local commission is responsible for guidance for kindergartens, building space-time internet service. Third is to build institutions such as service centers and parent-child gardens in communities and counties with high-quality kindergartens at its core which provides early learning activities. As a result, a education internet service structure of city-driving-country, high-quality kindergarten-leading-common kindergarten could be formulated.

\subsection{Child Education-care Integration}

Age between zero to six is the beginning of one's life, a relatively integral phase and thus an integral education must be applied. Childcare integration is to unify nursing education. Education between age of zero to three is known to the public and is brought into national education system. It's a priority to conclude three year old children into the target of early education (DFEE, 2000). The purpose of childcare education is to respect development of early childhood and provide early education service for children between zero to six and their family and through their unification to better serve their purposes.

4.3.1 Speed Up the Legislation of Preschool Education and Make Clear Responsibilities of government, Society and Family

(Yu, 2008) To speed up the legislation of preschool education is legal protection to realize childcare integration. Early Childhood Education Law highlights its importance. Therefore under the effects of government institution, legislatures enact early childhood education law as soon as possible. From the level of state will, value of child education between zero to six as well as the functions of government, society and family should be verified. First is to integrate education concept of childcare integration and focus on its purpose, content, application and assessment according to the law of physical and mental development of children between zero to six. Guided by the concept, clarify responsibilities of government, society and family so to unify resources to better serve its purpose. Second is to make laws to clarify duties and rights of each department and its management and make clear properties of nursery and kindergartens, their management and operation systems. In addition, lay down laws in terms of courses. Experts design course frames directed at early education to provide blueprint for preschool educators.

4.3.2 Improve the System of Teachers' Qualification Examinations, Attaches Great Importance to the Nursery and the Cultivation of Professional Teachers

Cultivation of teachers is the safeguard of childcare institutions to provide qualified nursing and education service. They should have professional knowledge of a teacher and a nursery governess. Public foundational courses of childcare teachers and educators will be established which pass relevant course identification to ensure that they have such knowledge and abilities. Infant teachers' certificate system will be applied to strengthen its importance. Qualification of preschool teachers will be applied by institutions identified by national or local department in charge through national or provincial examination so to form a standard team. 
There will be a new re-authentication of teachers' qualification and a valid period of teachers' certificates so that teachers will renew their education concept, knowledge and capabilities. Teachers' training methods are various. Training at different levels will be carried out, such as discipline leaders training and core teachers training. Besides teachers' needs will be taken into consideration in training, so there are nursing knowledge training, general knowledge training, professional knowledge training and skill training.

4.3.3 Strengthening Institutional Construction and Attaching Importance to the Supervision, Management and Evaluation

It's the basic guarantee of childcare integration to transfer functions of government education departments and improve supervision and quality assessment of preschool institutions. First, we should build quality detection appraisal system. There will be a separation of management, supervision and assessment department in preschool institution. Each institution will publish regularly its structural indicators and information. A third part will be entrusted to join the evaluation. Second is to lay down standards of kindergartens and apply strict admission system of private kindergartens. The administrative departments of education enact standards of running kindergartens according to state laws and regulations to establish standardized kindergartens. Government and relevant organizations strengthen management of unlicensed kindergartens with professional guidance and rectification and those illegal kindergartens will be shut down. Third, we should build a common system of supervision, management and evaluation of government-run and nongovernment-run kindergartens. With such a comprehensive system, both government-run and nongovernment-run kindergartens are under the same supervision system to ensure a fair and high-quality education.

\section{Conclusion}

Preschool education integration means that while focusing on fairness and high quality. It is to a fusion of urban-rural education, education and social service and daycare and childcare education so to achieve goal and maximally realize the aim of unification of education process and consequence. Through the analysis of its inner meaning, the methods are as the following: firstly, it is the reform of personnel system, investment system and supply and demand system so to build urban-rural integration of preschool education; secondly, social forces are encouraged to establish kindergartens and service institutions and provide comprehensive service for children development. Relevant departments will be integrated and internet service system will be built; thirdly, the government, society and family each should serve their own duty, and more and more attention should paid to the training of teachers and babysitters as well as supervision, management and evaluation of early education organizations.

\section{References}

Cao, N. X. (2009). Preschool comparative education (pp. 99-101). Shanghai: East China normal university press.

Cao, Y., \& Li, G. (2011). Restructure of Teachers' Personnel System under the Angle of Urban-rural Education Integration. Education Science Research, (5), 14.

Feng, X. X. (2000). Early childhood education (p. 191). Changchun: Jilin education press.

Morrison, G. (2004). Early Education in America (pp. 45-50). Beijing: Peking University Press.

He, F. (2012). A General Statement of Nursery Integration of Children between Zero to Six in New Zealand, Britain and Taiwan. Early Education (Education Science Research), (1), 28.

HM Treasury. (2003). Every Child Matters (Green Paper). London: The Stationery Office. Retrieved September 20, 2008, from http://www.everychildmat-ters.gov.uk

Lv, P., \& Zhong, Y. Y. (2010). Education Development under the Angle of Urban-rural Balanced Development. Early Childhood Education (Education Science), (10), 19.

UK Parliament. (2006). Childcare Act 2006. Retrieved November, 2008, from http://www.opsi.gov.uk.

Yu, Y. P. (2008). Policy Orientation and Course Concept of Nursery Integration. Preschool Course Research, (6), 4

Yu, Y. P. (2009). The basic relations and policy recommendations in the children (0-6) education and care integration system. Early Childhood Education (Science Education), (12), 7.

Zhang, H., Li, Y., \& Fan, Y. (2011). A General Statement and Enlightment of Preschool Education Integration in New Zealand, Britain and Taiwan. Early Childhood Education (Science Education), (10), 53.

Zhang, W. (2012). The era of the integration of urban and rural education. Education fairness demands 
(Education research), (8), 13.

\section{Copyrights}

Copyright for this article is retained by the author(s), with first publication rights granted to the journal.

This is an open-access article distributed under the terms and conditions of the Creative Commons Attribution license (http://creativecommons.org/licenses/by/3.0/). 